the botanist at the Bishop Museum, on a recent collecting tour on Kauai, had collected a number of dead specimens of this rare Lucanid beetle.

Pycnophion fuscipennis.-Mr. Bridwell also reported that Mr. Forbes collected this Ophionid on Kauai.

Megachile palmarum.-Mr. Timberlake reported that in examining collections of this bee he had separated out some which are of a different species, hitherto not recognized. This makes the fourth species of Megachile known here. Some specimens of it bore date of 1902 ; and were collected at the Government Nursery.

Alphitobius sp.-Mr. Fullaway exhibited specimens of a Tenebrionid beetle near to this genus, collected by Mr. Ehrhorn in destroying a nest of the fire ant on the waterfront.

Hormiopterus sp.-Mr. Fullaway exhibited specimens of this and another Braconid near Eubadizon which had been in the collections a long time without notice.

\title{
Notes on Some of the Immigrant Parasitic Hymenoptera of the Hawaiian Islands.
}

BY P. H. TIMBERLAKE.

During a recent visit in Washington, D. C., the writer compared certain of our introduced or immigrant parasitic Hymenoptera with types or other specimens in the U. S. National Museum. The comparisons in some cases confirmed previous determinations, but brought to light errors of identification in other cases. The writer's thanks are due to Mr. A. B. Gahan for aid in the determination of several species.

Ichneumonidae.

Exochus femoralis (Foureroy). A female from Honolulu (Oct. 16, 1916) was found identical with a female from

Proc. Haw. Ent. Soc., III, No. 5, April, igi8. 
Blankenburg, Thüringen, Germany, except for a slight difference in the degree of infuscation of the head.

Hemiteles tenellus (Say). Ashmead divided our Hemiteles among three so-called species, namely tenellus (Say), variegatus Ashmead and melitaeae Ashmead. Ever since the writer became acquainted with the character of the Hawaiian fauna he had been skeptical about these determinations. It seemed improbable, to say the least, that three closely allied species should become established here, and moreover all the material that was extant in the local collections was clearly referable to a single species. A study of the Hemiteles in the National Museum showed that the following described forms are extremely alike and might well belong to a single species, although showing some variations in size and coloration. The list includes tenellus (Say), utitis Norton, and the following all described by Ashmead: melitaeae, variegatus, coleophorae, orgyiae and periliti, the last two under Otacustes. Although there may be more than one species included here it would be hopeless to attempt to distinguish more than one by means of any descriptions so far published, and until the genus receives a thorough revision at the hands of a competent specialist, the writer recommends that the earliest American name, or tenellus (Say), be used for our Hawaiian parasite. In his work on the Hymenoptera of Connecticut, Viereck goes one step further and makes tenellus a variety or subspecies of the European areator (Panzer). This parasite has been reared frequently in the Islands from the cocoons of Chrysopa microphya McLachlan. It is probably distributed on all of the Islands, as the writer has seen it from Kauai, Oahu and Hawaii.

Angitia poiynesialis (Cameron). Viereck's species plutellae and hellulae are synonymous with Cameron's polynesialis. Viereck separated his two species on the presence or absence of yellowish markings on the sides of the abdomen. Hawaiian specimens usually have the yellowish markings and are thus identical with the types of hellulae. Such specimens 
have been reared in the United States from Plutella maculipennis Curtis and this is the usual host here. It is also not mlikely that this species occurs in Europe and an earlier name may possibly be found for it.

\section{Braconidae.}

Ephedrus incompletus (Provancher). Our Ephedrus was determined by Mr. Gahan as Provancher's species. It has been reared by the writer from a green species of Macrosiphum on rose bushes at Honolulu, and Mr. Swezey obtained it from the same host at Wailuku, Maui, on June 18, 1916. This species seems to have been first collected by Dr. Lyon on April 18, 1914, on the same host.

Diaeretus chenopodiaphidis (Ashmead). Our species of Diaeretus is not rapae (Curtis), but Ashmead's species which is chiefly distinguished by having 13 antennal joints in the female and 16 in the male, instead of 14 and 17 respectively, and by a slight difference in coloration and sculpture. This species has been reared from Aphis brassicae Linnaens, and Rhopalosiphum persicae (Sulzer) from several localities near Honolulu.

Dinocampus terminatus (Nees). The writer has examined specimens of this species from Hungary; Barcelona, Spain; Palroa, New Zealand; Fiji; Okitsu, Japan; and from many localities in the United States from Massachusetts and Virginia to California and Washington. Perkins also records it from Queensland, Australia. Perititus americanus Riley and Euphorus sculptus Cresson are synonyms, (the latter synonymy taken from a female in the National Museum which was compared with Cresson's type by Mr. R. A. Cushman). The species is extremely constant throughout its vast range, and although there is a slight variation in color this seems to be independent of its geographic distribution. In the Hawaiian Islands it was probably introduced with Olla abdominalis (Say) from North America, but it now usually attacks Coel- 
ophora inaequalis (Fabricius). It does not seem to be nearly so common here now, as it was when Perkins first found it.

A panteles sp. According to Mr. Gahan, our banded-winged Apanteles is entirely distinct from any known North American species. The species was first taken in 1911 at Honolulu, unless it is one of those mentioned by Perkins in 1910 without name or description. Mr. Swezey has reared it from Opogona.

Opius sp. The small Opius that has been reared recently by Messrs. Swezey, Bridwell, and the writer from the Lantana Agromyza on Oahu was determined by Mr. Gahan as most probably a new species close to nanus Provancher.

Hormiopterus sp. This is another recent immigrant which has been taken in Honolulu, Palolo, Niu, Kuliouou, and on Tantalus by several collectors. The first specimens examined by the writer were taken by Mr. Swezey in 1914.

\section{Pteromalidae.}

Pachyneuron siphonophorae (Ashmead). This species is readily recognized in the female sex by having three ring-joints and only five funicle joints. Mr. A. A. Girault has recently erected a new genus or subgenus, Propachyneuronia, for this species, but it is hardly worth recognition as the male sex does not show the supposed generic character. He has also synonymized Pachyneuron micans Howard and P. aphidivorum Ashmead with it, the latter incorrectly, as Mr. Gahan's notes on the types, taken when they were in a better state of preservation than at present, show that aphidivorum has only two ringjoints.

This species is hyperparasitic in Aphidids, and with us attacks both Ephedrus incompletus and Diaeretus chenopodiaphidis. It has been found at or near Honolulu, and at Wailuku, Maui, by Mr. Swezey.

Pachyneuron syrphi (Ashmead). This species was reared 
from a puparium of Xanthogramma grandicorne Macquart, from the plantation of the Oahu Sugar Company in April, 1904, by F. W. Terry. Apparently it is not common here. In the United States it has a wide range of Syrphid hosts, apparently all aphidivorous or coccidivorous species however, and is widely distributed. It is a primary parasite of the Syrphids and in consequence beneficial to the Aphidids and inimical to man.

$\mathrm{Mr}$. Girault has synonymized this species with albutius Walker, but the recognition of Walker's species is extremely doubtful from the descriptions alone. Mr. Girault's recent synopsis of the North American species of Pachyneuron is marred by too much reliance being placed on colorational characters, and does not prove to be very helpful in the identification of the species.

\section{Encyrtidae.}

Encyrtus infelix (Embleton). This is the species which was wrongly determined by Ashmead as Encyrtus fuscus (Howard). Infelix is a widely distributed species parasitic on Saissetia hemisphaerica (Targioni). The writer has seen it from Edinburg, Scotland; South Kensington, England; Torto, Portugal; and San Francisco and Sacramento, California. Masi has recently recorded it from the Sychelles Islands.

Blepyrus mexicanus Howard. The writer is unable to distinguish the three species of Blepyrus described by Howard, after a careful comparison of the types with a large series from Honolulu. Mexicanus was described from Monterey and was reared from a host said to be Ceroputo yuccae (Coquillett). The host remains mounted with the types, however, show the long, glassy filiaments so characteristic of Pseudococcus virgatus (Cockerell) and an error of identification is evident. Texanus was described from Brownsville, Texas, and the recorded host is $P$. virgatus which is definitely known to be the only host of Blepyrus here, described by Howard under the name of marsdeni. Coccophoctonus dactylopii Ashmead is 
another synonym of Blepyrus mexicanus. Ashmead recorded his species from Australia and eited an undetermined Pseudococcus as the host. The eleven type specimens, however, are labeled Honolulu and bear the same Insectary No. (of the U. S. Department of Agriculture) and date as Howard's types of marsdeni, so that undoubtedly both series were reared from the same lot of material.

Aphelinidae.

Prococcophagus orientalis (Howard). Our abundant, small, banded-winged Coccophagus-like parasite of Lecaniine scales, seems to be altogether too close to Howard's species for separation. The usual size of our specimens is nearly twice that of the types and the coloration of the pleura and legs is blacker. The types, however, are evidently undersized specimens, and have been considerably bleached by the action of alcohol in which they were preserved at some former time. The species has been recorded in the local literature variously as Coccophagus orientalis, Aneristus sp. and Aneristus ceroplastae. It seems to agree very well with Silvestri's conception of Prococcophagus, and is kept out of Aneristus by the absence of well developed bristles on the hind tibiae.

This is one of our most efficient coccid parasites, and has a wide range of hosts. It is extremely active, and carries the abdomen tilted upward.

Figitidae.

Eucoilidea micromorpha Perkins. This is clearly congeneric with Ashmead's genotype species, and is distinct from any of the species in the National Museum. It is parasitic in the puparia of Agromyza pusilla Meigen and has a wide distribution on Oahu, chiefly in the lowlands. 


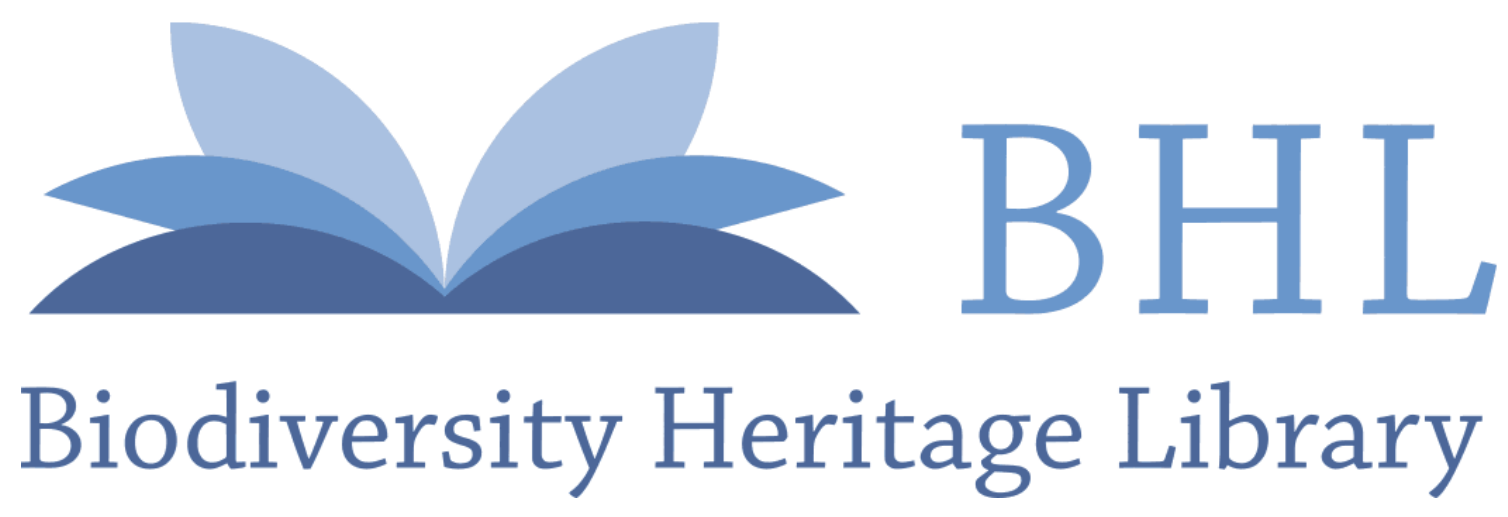

Timberlake, P. H. 1918. "Notes on some immigrant parasitic Hymenoptera of the Hawaiian islands." Proceedings of the Hawaiian Entomological Society 3, 399-404. https://doi.org/10.5962/bhl.part.24604.

View This Item Online: https://www.biodiversitylibrary.org/item/41056

DOI: https://doi.org/10.5962/bhl.part.24604

Permalink: https://www.biodiversitylibrary.org/partpdf/24604

\section{Holding Institution}

Smithsonian Libraries

\section{Sponsored by}

Smithsonian

\section{Copyright \& Reuse}

Copyright Status: NOT_IN_COPYRIGHT

This document was created from content at the Biodiversity Heritage Library, the world's largest open access digital library for biodiversity literature and archives. Visit BHL at https://www.biodiversitylibrary.org. 